\title{
Bretylium tosylate in prevention of cardiac dysrhythmias after myocardial infarction
}

\author{
S. H. Taylor, C. Saxton, P. S. Davies, and J. B. Stoker \\ From the Cardiovascular Unit and Department of Medicine, University of Leeds, and the \\ Coronary Care Unit, St. Fames's Hospital, Leeds, Yorks.
}

The prophylactic value of parenterally administered bretylium tosylate against the onset of dysrhythmias after acute myocardial infarction has been assessed by a controlled trial in Ior male patients. Bretylium significantly reduced the incidence of supraventricular dysrhythmias but was without significant effect on the incidence of ventricular dysrhythmias. The only serious side-effect of the drug was hypotension which occurred in one-third of the patients. It is concluded that prophylactic treatment of patients suffering from uncomplicated myocardial infarction with parenteral bretylium tosylate probably does not confer sufficient clinical benefit to warrant its recommendation for preventative use in this disease.

The most frequent major clinical complication after myocardial infarction in man is the development of a serious cardiac dysrhythmia, which immediately increases the morbidity and mortality. Any treatment that could be expected to reduce the incidence of such dysrhythmias would be a major therapeutic advance. However, the majority of drugs routinely used in the treatment of established abnormalities of rhythm have rarely been used prophylactically, in spite of the fact that prevention rather than the treatment of already established dysrhythmias is more likely to improve the over-all mortality of the disease.

Though bretylium tosylate was first introduced into clinical practice in 1960 , its antidysrhythmic properties were unnoticed until Leveque in 1965 noted its protective effect in experimentally induced atrial fibrillation in dogs. Bacaner (1966, 1968a) has since reported that in dogs bretylium not only affords protection against ventricular fibrillation but also is more effective in this respect than quinidine, procainamide, lignocaine, phenytoin, or propranolol. More recent studies have confirmed these observations in patients with serious cardiac dysrhythmias after myocardial infarction and cardiac operation (Bacaner, 1968b; Richards and Jerde, 1969; Castaneda and Bacaner, 1969).

In view of the therapeutic importance of these observations, it was decided to assess the value of bretylium tosylate in the pre-

Received I October 1969. vention of serious abnormalities of cardiac rhythm in patients after acute myocardial infarction.

\section{Patients and methods}

Included in the trial were ror male patients, aged between 34-65 years, who had suffered an acute myocardial infarction during the previous 24 hours. All patients satisfied the following diagnostic criteria: (I) the presence in the electrocardiogram of pathological $Q$ waves accompanied by elevation of the ST segment and later $T$ wave inversion, or changes in the ST segment and $T$ wave suggestive of infarction; (2) a rise in serum transaminase greater than 40 units $/ \mathrm{ml}$. Patients at the time of admission with heart failure, circulatory shock, heart block, sinus bradycardia, atrial fibrillation, supraventricular tachycardia, ventricular dysrhythmias, or recurrent premature ventricular contractions of more than 5 a minute were excluded from the trial. 21 patients had received morphine and ig pethidine before admission. Historical data documented for each patient included the time elapsing between onset of pain and admission, a history of previous myocardial infarction, angina, or hypertension, and a resume of smoking habits.

Patients were admitted to the Coronary Care Unit at St. James's Hospital. The electrocardiogram was continuously displayed on an oscilloscope; an associated heart rate meter was preset to trigger an audio-visual alarm whenever the rate fell outside the limits of 50-120 beats per min. Blood pressure was recorded hourly by sphygmomanometer during the day and 4-hourly at night. Patients were nursed in bed, usually in the sitting position during the day. Bedside commode facilities were allowed. As the disease 
was uncomplicated in all patients admitted to the trial, no other drug therapy was given during the trial other than mild hypnotics, if required, at night.

\section{Design of trial}

Patients accepted for inclusion in the trial were allocated alternately to treatment with bretylium, except that when a patient was withdrawn from the trial for clinical reasons, the next patient entering the trial was given the same treatment as that of the patient withdrawn. This method was used to ensure continued numerical balance of the two groups. The only patients withdrawn were from the bretylium-treated group (see below).

Treatment with bretylium consisted of intramuscular injections of $300 \mathrm{mg}$. at a concentration of $50 \mathrm{mg} . / \mathrm{ml}$. every six hours for five days. This represented a total dose range of $3 \cdot 6-4 \cdot 7 \mathrm{mg} . / \mathrm{kg}$. body weight, with a mean injected dose of $4 \cdot 15 \pm$ $0.040 \mathrm{mg} . / \mathrm{kg}$. (SD =0.248).

The incidence of dysrhythmias and the mortality during the five-day trial period in the two groups was compared and the results were analysed at frequent intervals to detect as early as possible any significant effects of the treatment. Statistical analyses were based on orthodox methods (Fisher, 1944).

\section{Results}

Of IoI patients with myocardial infarction admitted to the trial, 63 were given bretylium. Treatment with bretylium was stopped in 25. In 4 patients treatment was discontinued due to severe nausea and vomiting; in the remaining $2 \mathrm{I}$ patients treatment was stopped because of hypotension. In one patient this was associated with a further myocardial infarction and in two others syncope occurred on standing.

The average blood pressure of this group of 25 patients at the time of stopping treatment was $65 / 40 \mathrm{~mm}$. $\mathrm{Hg}$, and the mean number of doses of bretylium administered before treatment was stopped was 3.7. The factors of age, weight, clinical state of these patients before admission to the trial, and site of infarction showed no bias compared with those of patients remaining in the trial.

Thirty-eight patients received the full five-day course of treatment with bretylium, and there were 38 controls. The effect of bretylium on mortality is shown in Table $I$.

Though fewer of the bretylium-treated patients died than the controls, this difference can be attributed to chance. To establish whether bretylium reduces the mortality by 25 per cent would require an impracticably long study.

Treatment with bretylium significantly reduced the incidence of dysrhythmias sufficient to activate the alarm signal (Table 2).
TABLE I Effect of bretylium on mortality rate

\begin{tabular}{llll}
\hline Group & Died & Survived & $\begin{array}{l}\text { Mortality } \\
\text { rate }\end{array}$ \\
\hline $\begin{array}{l}\text { Control } \\
\begin{array}{l}\text { Bretylium com- } \\
\text { pleted }\end{array}\end{array}$ & 5 & 33 & $0.13^{\star}$ \\
$\begin{array}{l}\text { Bretylium stopped } \\
\text { 2 }\end{array}$ & 34 & $0.11^{\star}$ \\
\hline Total & I I & 90 & \\
\hline
\end{tabular}

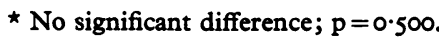

TABLE 2 Incidence of alarm-activating dysrhythmias

\begin{tabular}{|c|c|c|c|}
\hline Group & Alarm & No alarm & Alarm rate \\
\hline Control & 16 & 22 & $0.42^{\star}$ \\
\hline $\begin{array}{l}\text { Bretylium com- } \\
\text { pleted }\end{array}$ & 8 & 30 & $0.2 I^{\star}$ \\
\hline Bretylium stopped & 5 & 20 & 0.20 \\
\hline
\end{tabular}

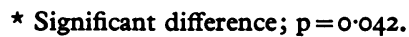

TABLE 3 Types of dysrhythmia

\begin{tabular}{lll}
\hline & $\begin{array}{l}\text { Bretylium } \\
\text { completed }\end{array}$ & Control \\
\hline Sinus bradycardia & 0 & I \\
Supraventricular tachycardia & 0 & 7 \\
Ventricular tachycardia & 5 & 4 \\
Ventricular fibrillation & I & I \\
Sudden death & 2 & 3 \\
\hline
\end{tabular}

* This group is assumed to have had a ventricular dysrhythmia before death.

The types of dysrhythmia triggering the alarm are shown in Table 3.

If the dysrhythmias are grouped as 'supraventricular tachycardias' and 'other dysrhythmias', $\chi^{2}$ is $3.05(0.10>p>0.05)$. It therefore appears that bretylium may exert a differential effect on the incidence of supraventricular and other dysrhythmias.

Fisher's exact probability (single-tailed) test applied to the incidence of supraventricular tachycardia and ventricular dysrhythmias (including sudden death) in the two groups is $p=0.006$ and $p=0.610$. In this group of patients, therefore, there is no evidence that bretylium influences the incidence of ventricular dysrhythmias, but there is a strong probability that bretylium reduces the incidence of supraventricular dysrhythmias.

The possibility that dysrhythmias or deaths in the bretylium-treated group might have 
occurred before bretylium could be expected to have exerted an effect was examined by comparing the interval between entry to the trial and the onset of dysrhythmia, and also by comparing the time elapsed from the onset of dysrhythmia to death in the two groups. It can be seen from Table 4 that there was no difference between the two groups.

TABLE 4 Mean hours ( $\pm S E$ ) elapsing between entry to trial and onset of dysrhythmia, and onset of dysrhythmia and death

\begin{tabular}{lll}
\hline & $\begin{array}{l}\text { Entry to trial } \\
\text { to onset of dys- } \\
\text { rhythmia }\end{array}$ & $\begin{array}{l}\text { Onset of dys- } \\
\text { rhythmia to } \\
\text { death }\end{array}$ \\
\hline $\begin{array}{l}\text { Control } \\
\text { Bretylium com- } \\
\text { pleted }\end{array}$ & $25 \cdot 4^{\star} \pm 6 \cdot 3(16) 1 \cdot 6^{\star} \pm 0.6 \quad(5)$ \\
\hline
\end{tabular}

Number of patients in each group in parentheses.

$\star$ No significant difference.

Factors that might have influenced the mortality and incidence of dysrhythmias in the two groups were examined. These included a previous history of myocardial infarction or angina, previous history of hypertension, age, weight, the number of cigarettes smoked daily, and the interval between onset of pain and admission. No significant differences were observed for any of these factors between the two groups.

\section{Discussion}

The present studies were designed to assess the therapeutic effectiveness of bretylium tosylate in the prevention of serious cardiac dysrhythmias immediately after myocardial infarction. Three important observations have been made: (I) the drug significantly reduced the incidence of supraventricular tachycardias in patients in the first five days after acute myocardial infarction but did not reduce the frequency of serious ventricular dysrhythmias; (2) the mortality trend in the patients receiving bretylium was less than that in the control group but in the relatively small number of patients studied the difference was not statistically significant; (3) the most important side-effect of the drug was hypotension which in one-third of the patients was of such magnitude that further therapy was discontinued. These observations are worthy of further comment.

The majority of drugs with antidysrhythmic potency exert their effects on the heart either through their beta-receptor blocking action or through their quinidine-like local anaesthetic activity. Drugs in which the former property predominates may, for physiological reasons, be expected to suppress secondary sympathetically-induced dysrhythmias arising in the supraventricular region more effectively than those arising directly from localized areas of injury in the ventricular myocardium. The latter dysrhythmias may equally be expected to respond more effectively to drugs with local anaesthetic activity which reduce the rate of rise of the intracellular action potential and decrease conduction velocity. Bretylium has been shown to be a potent blocker of sympathetic receptors in the heart, probably by effecting a block between the autonomic neurone or its transmitter release mechanism and the receptor site on the myocardial cell (Gilmore and Siegel, 1962). In addition, the drug has been shown to have no significant effect on the transmembrane potential in heart muscle and to have little local anaesthetic activity (Papp and Vaughan Williams, 1969). On this basis the mode of action of bretylium in cardiac dysrhythmias could be expected to differ significantly from that of the quinidine-like compounds and to be selectively effective against secondary sympathetically-induced dysrhythmias. In fact, Leveque (1965) has shown the potent inhibitory effect of bretylium, in doses within the human therapeutic range, against experimentally induced atrial fibrillation in the dog. These arguments lend theoretical and experimental support to the findings in the present study that the drug appeared to be selectively effective in preventing the onset of dysrhythmias of supraventricular origin.

Though these observations are in apparent conflict with the previous reports of the effectiveness of the drug against experimentally induced ventricular dysrhythmias, one explanation of this difference in the findings may be due to the dose of bretylium used. Bacaner and his colleagues (Bacaner, 1966, 1968a; Castaneda and Bacaner, 1969) found that experimentally induced ventricular fibrillation was frequently reverted or protected against by injections of bretylium greater than ro mg./kg. body weight and usually of the order of $20 \mathrm{mg} . / \mathrm{kg}$. body weight. They noted that below a dose level of $10 \mathrm{mg}$. $/ \mathrm{kg}$. body weight, the response was critically dose dependent. In the present studies the mean injected dose of bretylium was $4.15 \mathrm{mg}$. $/ \mathrm{kg}$. and never exceeded $5 \mathrm{mg}$. $/ \mathrm{kg}$. body weight. Also, Leveque (1965) found a linear log-doseresponse relation in the protective effect of bretylium against induced dysrhythmias in dogs; no antidysrhythmic protection was 
afforded at an injected dose level lower than $2.5 \mathrm{mg}$. $/ \mathrm{kg}$., with full protection at a dose level of $30 \mathrm{mg} . / \mathrm{kg}$. More recently, Allen, Shanks, and Zaidi (1969) have furnished similar experimental evidence. Protection against ventricular dysrhythmias induced by adrenaline or ouabain in dogs was provided by bretylium only when the intravenous dose exceeded $20 \mathrm{mg}$. $/ \mathrm{kg}$. body weight.

On this evidence the single injected doses of bretylium of less than $5 \mathrm{mg}$. $/ \mathrm{kg}$. body weight used in the present study could not be expected to suppress locally-induced dysrhythmias of direct ventricular origin. However, larger doses of bretylium probably cannot be safely used after myocardial infarction. In the patients in the present study the disease was uncomplicated by any clinically apparent circulatory decompensation. Even so, in more than one-third of these patients the drug had to be discontinued due to the development of severe hypotension.

However, consideration of the sequence of physiological events that occur after myocardial infarction suggests a possible use for bretylium in the treatment of this disease. Myocardial infarction, even in uncomplicated cases, is usually accompanied by evidence of increased sympathetic drive (Jewitt et al., 1969a). This increased sympathetic activity may have the undesirable effect of precipitating supraventricular dysrhythmias; this complication could possibly be prevented by pretreatment with bretylium. It is unlikely that the drug would be as effective in protecting against those ventricular dysrhythmias arising directly from the damaged myocardium; these dysrhythmias could be expected to be best controlled by drugs with direct effects on the cardiac cell membrane. Clinical evidence in support of this supposition is the recent report that beta-blocking drugs are predominantly effective against the supraventricular dysrhythmias that arise after myocardial infarction (Jewitt, Mercer, and Shillingford, 1969b). However, before considering the routine prophylactic use of bretylium in patients with acute myocardial infarction, the clinical benefits likely to accrue to the patient must be weighed against the risks of the hypotension that so frequently results from its use.
The authors wish to thank the physicians of St. James's Hospital for allowing us to study their patients, Professors Sir Ronald Tunbridge and R. Linden for their help and encouragement, Dr. E. M. Vaughan Williams of the Universitv of Oxford Department of Pharmacology, for his help and advice, and Sister Dewitt and the nursing staff of the Coronary Care Unit, St. James's Hospital, for their invaluable help throughout. The authors also wish to thank Dr. A. D. Munro-Faure, Clinical Research Department, and Mr. E. Knight, Statistical Department, The Wellcome Foundation, for their help with the statistical design of the trial and technical advice. One of the authors (C. S.) is a Research Fellow of the Leeds Regional Hospital Board.

\section{References}

Allen, J. D., Shanks, R. G., and Zaidi, S. A. (1969). A comparison of the effects of bretylium, lignocaine and propranolol on experimental cardiac arrhythmias. (Abstr.) British fournal of Pharmacology and Chemotherapy, 36, 526.

Bacaner, M. (1966). Bretylium tosylate for suppression of induced ventricular fibrillation. American fournal of Cardiology, 17, 528.

- (1968a). Quantitative comparison of bretylium with other antifibrillatory drugs. American fournal of Cardiology, 21, 504.

- (1968b). Treatment of ventricular fibrillation and other acute arrhythmias with bretylium tosylate. American fournal of Cardiology, 21, 530 .

Castaneda, A. R., and Bacaner, M. (1969). Prophylactic suppression of postoperative arrhythmias with bretylium tosylate in open heart surgery. (Abstr.) American fournal of Cardiology, 23, 107.

Fisher, R. A. (1944). Statistical Methods for Research Workers, 9th ed. Oliver and Boyd, Edinburgh.

Gilmore, J. P., and Siegel, J. H. (I962). Mechanism of the myocardial effects of bretylium. Circulation Research, 10, 347.

Jewitt, D. E., Mercer, C. J., Reid, D., Valori, C., Thomas, M., and Shillingford, J. P. (1969a). Free noradrenaline and adrenaline excretion in relation to the development of cardiac arrhythmias and heart-failure in patients with acute myocardial infarction. Lancet, 1, 635.

,-- , and Shillingford, J. P. (r969b). Practolol in the treatment of cardiac dysrhythmias due to acute myocardial infarction. Lancet, 2, 227.

Leveque, P. E. (1965). Anti-arrhythmic action of bretylium. Nature (London), 207, 203.

Papp, J. G., and Vaughan Williams, E. M. (I969). The effect on intracellular atrial potentials of bretylium in relation to its local anaesthetic potency. (Abstr.) British fournal of Pharmacology and Chemotherapy, 35, 352.

Richards, A. M., and Jerde, O. M. (1969). Bretylium tosylate and electroshock as combined therapy for intractable ventricular fibrillation and arrhythmias in myocardial infarction. (Abstr.) American fournal of Cardiology, 23, 134. 